\title{
Ontological Model of School Librarianship Based on Collaboration
}

\author{
Marija László, College Lecturer \\ Telephone: +38591528246, Fax:+38514829526 \\ E-mail: marijal@inet.hr \\ Dinka Kovačević, Associate Professor \\ Jasmina Lovrinčević, Professor \\ Josip Juraj Strossmayer University of Osijek, The Department of Cultural Studies, \\ Trg Sv. Trojstva 3, 31000 Osijek, Croatia
}

\begin{abstract}
Considering the definition of ontology as a common vocabulary for researchers (practitioners) who need to share information in a domain, we have established a set of concepts concerned with identifying, analyzing, describing and representing shared conceptualization in Croatian school librarianship. We have given a survey of research areas in the last 24 years. Approaching the problem of ontology, we applied it in the sense of information science, i.e., modeling language based on a common vocabulary and understanding when and how the modern concept of librarianship like media and information literacy, information needs, curriculum integration, e-learning etc. were introduced into Croatian school librarianship practice. The next step could be to dentify and to evaluate the strength of the various semantic links between found concepts. The key issue of school library ontology modeling is the answer to the question: how well the Croatian school librarian community is prepared to participate in building 21st century learning environments.
\end{abstract}

Keywords: ontology, information modeling, domain concepts, classification scheme, school librarianship, library and information science

\section{Introduction}

The Ministry of Science, Education and Sport of the Republic of Croatia in Europe, in order to share information and knowledge in school library activities, sponsors yearly conferences for school librarians, teachers, educators, artists and publishers in the field of education, libraries and learning environments. From the very beginning of these conferences in 1988 up to now, 24 volumes of conference proceedings have been published containing juried papers, descriptions of presented workshops, round table outcomes, and overviews of best practice examples considering school library roles in formal and informal education.

Subject analysis of the conference proceedings provided us with concepts representing knowledge (conceptualizations) dealing with school librarianship and related concepts. The first step was extracting the main concepts found as main conference themes, such as (1), subjects of juried papers (2), contents of workshops (3), and round table main topics (4). The collected vocabulary lists were classified 
according to the ALISE LIS Research Areas Classification Scheme. ${ }^{1}$ Classified sets of objects, i.e., collected vocabulary and describable relationships among them was the starting point for our school librarianship ontological model based on the bibliographic documentation, i.e. 24 volumes of conference proceedings.

Considering the definition of ontology as a common vocabulary for researchers (practitioners) who need to share information in a domain, we have established a set of concepts concerned with identifying, analyzing, describing and representing shared conceptualization in Croatian school librarianship. Approaching the problem of ontology, we applied it in the sense of information science, i.e., modeling language based on a common vocabulary and understanding when and how the modern concept of librarianship like media and information literacy, information needs, curriculum integration, electronic reference service, e-learning etc. were introduced and applied into Croatian school librarianship practice. In modeling our ontology scheme, we have reached the first step. We have given a survey of research areas in the last 24 years. The next step could be to dentify and to evaluate the strength of the various semantic links between found concepts.

Texts as a source of information have increasingly been used with the development of Internet. In order to extract the relevant information from texts, there has been a need to use tools capable to automatically extract terms or concepts. These terms and concepts can be used to obtain the knowledge contained in the documents. In bibliographic description the process of coding and retrieving the knowledge in the documents is called subject analysis. Subject analysis (generally called content analysis) is the process of identifying the intellectual content of a work. Subject is the theme or topic treated by the author in a work, whether stated in the title or not. The results may be displayed in a catalog or bibliography by means of notational symbols as in a classification system or by verbal terms such as subject headings or indexing terms 2 .

All these approaches have been termed ontologies. They are an extension of the philosophical term dating from Aristotle. In philosophy, ontology is the branch of metaphysics that deals with the nature and relations of being with respect to entities existing in the universe. The meaning is derived from the Greek first combining form (prefixoid) onto- of the participle 'being' (based on the gen. ontos) and the second combining form (suffixoid) -logíâ 'discourse, theory, science' coming from lógos 'word, speech, discussion'.

Philosophical ontology is descriptive, i.e. qualitative and it seeks taxonomy, not predication or explanation. Science is, in contrast, quantitative, it starts with measurement and prediction and strives to make taxonomies systematic. The original philosophical meaning of an ontology in science and applied science has come to mean a kind of knowledge organization. The term ontology has become popular outside philosophy in domains such as knowledge engineering, knowledge representation, information modeling, natural language processing, semantic web research, collaborative engineering design, cooperative information systems and many others relating to computer and information science.

The term knowledge organization systems is intended to encompass all types of schemes for organizing information and promoting knowledge management. Knowledge organization

\footnotetext{
${ }^{1} \mathrm{http} / / /$ www.alise.org/mc/page.do?sitePageId=55727\& $\operatorname{orgId}=$ ali

${ }^{2}$ http://www.sir.arizona.edu/resources/glossary.html
} 
systems include classification and categorization schemes that organize materials at a general level, subject headings that provide more detailed access, and authority files that control variant versions of key information such as geographic names and personal names. Knowledge organization systems also include highly structured vocabularies, such as thesauri, and less traditional schemes, such as semantic networks and ontologies. Because knowledge organization systems are mechanisms for organizing information, they are at the heart of every library, museum, and archive. (Hodge 2000).

Following Gruber's (1993) definition of ontology as "a specification of a conceptualization", "a specification of a representational vocabulary for a shared domain of discourse - definitions of classes, relations, functions, and other objects", or in simple terms, conceptualization as a structure consisting of a domain and a set of relevant relations, our first step has been extracting the main concepts found in main conference themes, such as (1) subjects of juried papers, (2) contents of workshops, and (3) best practice examples in school libraries. The collected vocabulary lists have been classified according to the ALISE LIS Research Areas Classification Scheme3. The main concept vocabulary list is taken the in the sense of domain-descriptive ontology as distinct from formal ontology. Domain-descriptive ontology is related to focus of study (see Table 1). Formal ontology abstracts the form of statements away from their content in order to establish abstract criteria of consistency and validity.

Descriptive ontology concerns the collection of such prima facie information either in some specific domain of analysis or in general. Formal ontology distills, filters, codifies and organizes the results of descriptive ontology (in either its local or global setting). According to this interpretation, formal ontology is formal in the sense used by Husserl in his Logical Investigations. Being 'formal' in such a sense therefore means dealing with categories like thing, process, matter, whole, part, and number. These are pure categories that characterize aspects or types of reality and still have nothing to do with the use of any specific formalism. (Poli).

The present article deals with the first step in modeling domain-descriptive ontology in school librarianship. Main concepts have been found in and extracted from 24 published volumes of school librarianship conference proceedings: in 340 articles that were presented orally on plenary sessions, 163 articles dealing with the workshops and their outcomes performed during the conferences and 237 articles describing best practice examples in Croatian school librarianship, i.e. 740 bibliographic items.

\section{Purpose}

Each research field has its own ontology and it provides a specific definition of the terms and vocabulary used in a certain area. School librarianship is a specific domain considering reading, learning and teaching using library materials. School

\footnotetext{
${ }^{3}$ http://www.alise.org/mc/page.do?sitePageId=55727\&orgId=ali
} 
librarian is trained to deliver library services to students, teachers and other school personnel. He or she (1) assists students with reading selections appropriate to reading level, (2) teaches research and library skills appropriate to grade level, (3) establishes standards of behavior for the library, (4) helps students in developing informationseeking skills and habits needed for lifelong learning, (5) supports the curriculum through collection development, and (6) cooperates with classroom teachers in integration library services and multimedia materials into instructional programs (Reitz).

In 24 volumes of Croatian school librarianship conference proceedings, we can follow written traces of the activities conducted under the auspices of Croatian school librarian community. They were described, discussed and performed during the period of 24 years. Our ontology is one way to establish a set of concepts concerned with identifying, analyzing, describing and representing shared knowledge in Croatian school librarianship. The first meaning of the word concept is a general idea derived or inferred from specific instances or occurrences.

Approaching the problem of ontology, we applied it in the sense of information science, i.e. modeling language based on a common vocabulary and understanding when and how the modern concepts of librarianship like media and information literacy, information needs, curriculum integration, electronic reference service, e-learning, etc. were introduced and applied into Croatian school librarianship practice during the period of 24 years.

The LIS (Library and Information Science) concepts introduced into Croatian school librarianship are understood as "the entities that populate bibliographic universe. Examples of such entities are works, editions, authors and subjects."

(Svenonious 31). They constitute the modeling design of our school librarianship ontology. The complete design of it together with the corresponding bibliographic data (entities) will be a publication for itself.

\section{Methodology and results}

In our research methodology, we had to think about the differences between qualitative and quantitative data. The qualitative data have been collected by indexing every bibliographic item. After completing the rough collection of index terms and the year of the conference, we have edited them for structure, clarity and consistency. Croatian index terms have been rendered into the appropriate terms found in ALISE LIS Research Areas Classification Scheme (http://www.alise.org/classification-scheme). The ALISE Scheme consists of an open list of entries marked by ordinal numbers. Ten main categories of research areas have been introduced up to now:

"Development/Principles of LIS, LIS Education, Collection Development, Services to User Populations, Informatics, Organization of Information, Information System and Retrieval, Types of Libraries and Information Providers, Management/Administration and School Libraries."

According to this classification scheme, school libraries are a research area for itself. For the purpose of our ontological model, we have replaced the category School Libraries with Curriculum. Unesco Education Thesaurus ${ }^{4}$ defines curriculum as

\footnotetext{
${ }^{4}$ http://www.ibe.unesco.org/fileadmin/user_upload/Publications/IBE_Thesaurus/TH_alpha_array_Oct07.pdf
} 
a plan incorporating a structured series of intender learning outcomes and associated learning experiences.

The described methodology has provided us with the overview of research areas in Croatian school librarianship. The qualitative data have been counted in order to get the quantitative data, i.e. conference years and frequency of theme found in conference proceedings. The data are summarized in Table 1 Total number of sessions per years.

The first column refers to the conference themes rendered in ALISE LIS Research Areas Classification Scheme. The second column indicates the conference years when the corresponding research area was discussed. The third column states the number of the corresponding sessions. The fourth column summarizes the total numbers of sessions in the main categories of ALISE LIS Research Areas Classification Scheme.

Table 1 Total number of sessions per years

\begin{tabular}{|c|c|c|c|}
\hline $\begin{array}{l}\text { Selection of items from } \\
\text { ALISE LIS Research } \\
\text { Areas Classification Scheme } \\
\text { (preceded by teir ordinal } \\
\text { numbers) }\end{array}$ & $\begin{array}{c}\text { Years of } \\
\text { conferences }\end{array}$ & $\begin{array}{l}\text { Number } \\
\text { of sessions }\end{array}$ & $\begin{array}{l}\text { Total number of sessions in } \\
\text { the Main Categories of } \\
\text { ALISE LIS Research Areas }\end{array}$ \\
\hline 4 LIS as a profession & $\begin{array}{l}1989,1998,2005 \\
2008,2012\end{array}$ & 5 & \multirow{5}{*}{$\begin{array}{l}\text { Total number of sessions on } \\
\text { Development/Principles of LIS } \\
15\end{array}$} \\
\hline $\begin{array}{l}5 \text { Philosophy, values and ethics } \\
\text { of LIS }\end{array}$ & 2001,2009 & 2 & \\
\hline 7 Libraries and society/Culture & $\begin{array}{l}1999,2000,2005 \\
2009\end{array}$ & 4 & \\
\hline 8 Information/Society culture & $1990,1992,1999$ & 3 & \\
\hline $\begin{array}{l}14 \text { Intellectual freedom and } \\
\text { censorship }\end{array}$ & 1993 & 1 & \\
\hline 15 LIS education and programs & $\begin{array}{c}1989,1998,2000, \\
2003,2004,2005,20 \\
10,2011\end{array}$ & 8 & \multirow{5}{*}{$\begin{array}{c}\text { Total number of sessions on } \\
\text { LIS education } \\
37\end{array}$} \\
\hline 17 Pedagogy in LIS & $\begin{array}{c}1989,1991, \\
1993,1996,2001 \\
\end{array}$ & 5 & \\
\hline 18 Research methods & $\begin{array}{l}1994,1996,2001 \\
2011,2012\end{array}$ & 5 & \\
\hline 20 Continuing education in LIS & $\begin{array}{l}1989,1996,1998, \\
2006\end{array}$ & 4 & \\
\hline $\begin{array}{l}21 \text { International/Comparative } \\
\text { librarianship }\end{array}$ & $1997-2012$ & 15 & \\
\hline 29 Arts/Humanities literatures & $1997,2000,2001$ & 3 & \multirow[b]{3}{*}{$\begin{array}{c}\text { Total number of sessions on } \\
\text { Collection Development } \\
9\end{array}$} \\
\hline 31 Government documents & 2010,2012 & 2 & \\
\hline 35 Electronic documents & $\begin{array}{c}1998,2002,2003 \\
2006\end{array}$ & 4 & \\
\hline $\begin{array}{l}44 \text { Services for people with } \\
\text { disabilities }\end{array}$ & 2002,2007 & 2 & \multirow[b]{4}{*}{$\begin{array}{l}\text { Total number of sessions on } \\
\text { Services to user populations } \\
\qquad 27\end{array}$} \\
\hline 45 Reading advisory service & $\begin{array}{c}2000,2004, \\
2010,2011\end{array}$ & 4 & \\
\hline 47 Storytelling & 1995,2011 & 2 & \\
\hline 48 Reading and literacy & $\begin{array}{l}1993,1995,1999, \\
2000,2002,2004, \\
2006,2007,2010, \\
2011\end{array}$ & 10 & \\
\hline
\end{tabular}




\begin{tabular}{|c|c|c|c|}
\hline $\begin{array}{l}49 \text { Information literacy and } \\
\text { instructions }\end{array}$ & $\begin{array}{c}1992,2002,2005, \\
2007\end{array}$ & 4 & \\
\hline $\begin{array}{l}50 \text { Information needs and } \\
\text { behaviors/practices }\end{array}$ & 1996 & 1 & \\
\hline $\begin{array}{l}53 \text { Scholarly and scientific } \\
\text { communication }\end{array}$ & $\begin{array}{c}1993,1994,1995, \\
2009\end{array}$ & 4 & \\
\hline 54 Organization of information & $\begin{array}{l}\text { 1990, 2000, 2002, } \\
2003\end{array}$ & 4 & \multirow{2}{*}{$\begin{array}{l}\text { Total number of sessions on } \\
\text { Organization of information } \\
5\end{array}$} \\
\hline $\begin{array}{l}57 \text { Classification and subject } \\
\text { analysis }\end{array}$ & 1994 & 1 & \\
\hline $\begin{array}{l}62 \text { Information systems and } \\
\text { technologies }\end{array}$ & $\begin{array}{c}1991,1993,1997, \\
2000,2008\end{array}$ & 5 & \multirow{7}{*}{$\begin{array}{l}\text { Total number of sessions on } \\
\text { Information systems and } \\
\text { retrieval } \\
21\end{array}$} \\
\hline $\begin{array}{l}63 \text { Information retrieval theory } \\
\text { and practice }\end{array}$ & 1996 & 1 & \\
\hline $\begin{array}{l}64 \text { Online catalog retrieval } \\
\text { systems }\end{array}$ & 1998,2003 & 2 & \\
\hline $\begin{array}{l}65 \text { Database and other retrieval } \\
\text { systems }\end{array}$ & $1998,1999,2008$ & 3 & \\
\hline 67 Information visualization & 1991,1993 & 2 & \\
\hline $\begin{array}{l}68 \text { Computers/Information } \\
\text { networks }\end{array}$ & $\begin{array}{l}\text { 1997, 2000, 2004, } \\
2010\end{array}$ & 4 & \\
\hline $\begin{array}{l}72 \text { Bibliometrics/Informetrics } \\
\text { /Webometrics }\end{array}$ & $\begin{array}{c}\text { 1993, 2000, 2011, } \\
2012\end{array}$ & 4 & \\
\hline 74 Digital/virtual libraries & 1998,2003 & 2 & \multirow{2}{*}{$\begin{array}{c}\text { Total number of sessions on } \\
\text { Types of libraries and } \\
\text { information providers } \\
5\end{array}$} \\
\hline $\begin{array}{l}77 \text { School media } \\
\text { centers/libraries }\end{array}$ & 1989, 1992, 2012, & 3 & \\
\hline 87 Buildings/facilities & $\begin{array}{l}1989,2002,2003 \\
2007\end{array}$ & 4 & \multirow{3}{*}{$\begin{array}{c}\text { Total number of sessions on } \\
\text { Management/Administration } \\
7\end{array}$} \\
\hline $\begin{array}{r}89 \text { Strategic, planning, } \\
\text { marketing, lobbying }\end{array}$ & 2001,2007 & 2 & \\
\hline 90 Evaluation of service & 2012 & 1 & \\
\hline 101 Curriculum integration & $2004,2009,2010$ & 3 & \multirow{3}{*}{$\begin{array}{c}\text { Total number of sessions on } \\
\text { Curriculum } \\
9\end{array}$} \\
\hline $\begin{array}{l}103 \text { Role of the school library } \\
\text { media specialist }\end{array}$ & $\begin{array}{c}1990,1991,1994, \\
2008,2012\end{array}$ & 5 & \\
\hline 104 Instructional design & 2012 & 1 & \\
\hline
\end{tabular}

Table 2 Groups of research areas represents the overview of the research areas in Croatian school librarianship encompassing 24 years. This table contains the vocabulary of research areas in which shared knowledge in Croatian school librarianship community is represented. This is the first step in our ontological modeling and it can be inerpreted as investigation into the structure of existence: the analysis and conceptualization of 'what there is'. The next step in futher modeling our school librarianship ontology is to define every used term and find out the relations among them. The identification of relations between concepts and terms is based on the distribution of contexts. For the traditional terminology a term means "term of the concept that ontology belongs to" (Gu 2005). The data in Table 2. confirm that the Croatian school librarian community is mostly interested in LIS education, in the services providing by school library, in information systems and in retrival and development of librarianship and applying their principles in their practice. They are also keep them occupied with the collection devolopment and curriculum integration. 


\begin{tabular}{|l|c|}
\hline \multicolumn{1}{|c|}{ Research areas } & $\begin{array}{c}\text { Numbers of } \\
\text { sessions during } \\
\text { 24 years }\end{array}$ \\
\hline $\begin{array}{l}\text { LIS education including international cooperation and comparative (school) } \\
\text { librarianship, programs, pedagogy, research methods, lifelong learnig, i.e. } \\
\text { continuing education. }\end{array}$ & 37 \\
\hline $\begin{array}{l}\text { Services to user populations including reading and literacy, reading advisory } \\
\text { service, information literacy, storytelling, scholarly and scientific communication, } \\
\text { organization of information, information needs. }\end{array}$ & 27 \\
\hline $\begin{array}{l}\text { Information systems and retrieval including information systems and } \\
\text { technologies, computers and nformation networks, biometrics, infometrics, } \\
\text { webometrics, database and other retrieval systems, online catalog retrieval } \\
\text { systems, information visualization. }\end{array}$ & 21 \\
\hline $\begin{array}{l}\text { Development/Principles of LIS including LIS as profession, libraries and society } \\
\text { and culure, information and society culture, intellectual freedom and censorship }\end{array}$ & \\
\hline $\begin{array}{l}\text { Collection Development including electronic documents, arts, humanities } \\
\text { literatures, government documents }\end{array}$ & 15 \\
\hline $\begin{array}{l}\text { Curriculum including curriculum integration, instructional design, role of scool } \\
\text { library media specialist. }\end{array}$ & 9 \\
\hline $\begin{array}{l}\text { Management/Administration including strategic, planning, marketing, lobbing. } \\
\text { evaulation of service. }\end{array}$ & 9 \\
\hline Organization of information including classification and subject analisys. & 7 \\
\hline $\begin{array}{l}\text { Types of libraries and information providers including digital libraries, school } \\
\text { media centers. }\end{array}$ & \\
\hline
\end{tabular}

Table 3 Distribution of research areas during 24 years indicates the distribution of the research areas during the 24 years. The columns show in which year of conferances (last two digits) particular research areas were treated. The rows give the overview of research areas discussed by the year. By inspection of the table it can be noticed that International and Comparative Librarianship is repeated from 1997 onwards. Teachers, librarians and other professions dealing with school librarianship outside Croatia took active part in the conferences.

Table 3 Distribution of research areas during 24 years

\begin{tabular}{|c|c|c|c|c|c|c|c|c|c|c|c|c|c|c|c|c|c|c|c|c|c|c|c|c|}
\hline \begin{tabular}{|l}
$\begin{array}{l}\text { Years of conference (last two } \\
\text { digits): }\end{array}$ \\
Research areas \\
\end{tabular} & $\begin{array}{l}8 \\
9\end{array}$ & $\begin{array}{l}9 \\
0\end{array}$ & $\begin{array}{l}9 \\
1\end{array}$ & $\begin{array}{l}9 \\
2\end{array}$ & $\begin{array}{l}9 \\
3\end{array}$ & $\begin{array}{l}9 \\
4\end{array}$ & $\begin{array}{l}9 \\
5\end{array}$ & $\begin{array}{l}9 \\
6\end{array}$ & $\begin{array}{l}9 \\
7\end{array}$ & $\begin{array}{l}9 \\
8\end{array}$ & $\begin{array}{l}9 \\
9\end{array}$ & $\begin{array}{l}\mathbf{0} \\
\mathbf{0}\end{array}$ & $\begin{array}{l}\mathbf{0} \\
\mathbf{1}\end{array}$ & $\begin{array}{l}\mathbf{0} \\
2\end{array}$ & $\begin{array}{l}\mathbf{0} \\
3\end{array}$ & $\begin{array}{l}0 \\
4\end{array}$ & $\begin{array}{l}\mathbf{0} \\
\mathbf{5}\end{array}$ & $\begin{array}{l}0 \\
6\end{array}$ & $\begin{array}{l}\mathbf{0} \\
7\end{array}$ & $\begin{array}{l}\mathbf{0} \\
8\end{array}$ & $\begin{array}{l}\mathbf{0} \\
\mathbf{9}\end{array}$ & $\begin{array}{l}1 \\
\mathbf{0}\end{array}$ & $\begin{array}{l}1 \\
1\end{array}$ & $\begin{array}{l}1 \\
2\end{array}$ \\
\hline 4 LIS as a Profession & 89 & & & & & & & & & 98 & & & & & & & $\begin{array}{l}0 \\
5\end{array}$ & & & $\begin{array}{l}0 \\
8\end{array}$ & & & & 12 \\
\hline $\begin{array}{l}5 \text { Philosophy, Values, and } \\
\text { Ethics of LIS }\end{array}$ & & & & & & & & & & & & & $\begin{array}{l}\mathbf{0} \\
1\end{array}$ & & & & & & & & $\begin{array}{l}\mathbf{0} \\
9\end{array}$ & & & \\
\hline 7 Libraries and Society/Culture & & & & & & & & & & & $\begin{array}{l}9 \\
9 \\
\end{array}$ & $\begin{array}{l}\mathbf{0} \\
\mathbf{0}\end{array}$ & & & & & $\begin{array}{l}\mathbf{0} \\
5\end{array}$ & & & & $\begin{array}{l}\mathbf{0} \\
\mathbf{9}\end{array}$ & & & \\
\hline $\begin{array}{l}8 \text { Information and Society / } \\
\text { Culture }\end{array}$ & & \begin{tabular}{l|}
9 \\
$\mathbf{0}$
\end{tabular} & & $\begin{array}{l}9 \\
2\end{array}$ & & & & & & 98 & & & & & & & & & & & & & & \\
\hline $\begin{array}{l}14 \text { Intellectual Freedom and } \\
\text { Censorship }\end{array}$ & & & & & $\begin{array}{l}9 \\
3 \\
\end{array}$ & & & & & & & & & & & & & & & & & & & \\
\hline 15 LIS Education and Programs & 89 & & & & & & & & & 98 & & $\begin{array}{l}\mathbf{0} \\
\mathbf{0}\end{array}$ & & & 03 & 04 & \begin{tabular}{|l|}
0 \\
5
\end{tabular} & & & & & 10 & & 12 \\
\hline 17 Pedagogy in LIS & 89 & & 91 & & 93 & & & $\begin{array}{l}9 \\
6\end{array}$ & & & & & $\begin{array}{l}\mathbf{0} \\
1\end{array}$ & & & & & & & & & & & \\
\hline 18 Research Methods & & & & & & 94 & & $\begin{array}{l}9 \\
6\end{array}$ & & & & & $\begin{array}{l}\mathbf{0} \\
1\end{array}$ & & & & & & & & & & $\begin{array}{l}1 \\
1\end{array}$ & 12 \\
\hline
\end{tabular}




\begin{tabular}{|c|c|c|c|c|c|c|c|c|c|c|c|c|c|c|c|c|c|c|c|c|c|c|c|c|}
\hline 20 Continuing Education in LIS & 89 & & & & & & & $\begin{array}{l}9 \\
6\end{array}$ & & 98 & & & & & & & & $\begin{array}{l}0 \\
6\end{array}$ & & & & & & \\
\hline $\begin{array}{l}21 \text { International/Comparative } \\
\text { Librarianship }\end{array}$ & & & & & & & & & 9 & 98 & $\begin{array}{l}9 \\
9\end{array}$ & $\begin{array}{l}\mathbf{0} \\
\mathbf{0}\end{array}$ & $\begin{array}{l}0 \\
\mathbf{1}\end{array}$ & $\begin{array}{l}\mathbf{0} \\
2\end{array}$ & 03 & 04 & $\mathbf{0}$ & 06 & 0 & $\begin{array}{l}\mathbf{0} \\
8\end{array}$ & $\begin{array}{l}\mathbf{0} \\
9\end{array}$ & 10 & $\begin{array}{l}1 \\
1\end{array}$ & 12 \\
\hline 29 Arts/Humanities Literatures & & & & & & & & & $\begin{array}{l}9 \\
7\end{array}$ & & & $\begin{array}{l}\mathbf{0} \\
\mathbf{0}\end{array}$ & $\begin{array}{l}\mathbf{0} \\
\mathbf{1}\end{array}$ & & & & & & & & & & & \\
\hline 31 Government Documents & & & & & & & & & & & & & & & & & & & & & & 10 & & 12 \\
\hline 35 Electronic Documents & & & & & & & & & & 98 & & & & $\begin{array}{l}\mathbf{0} \\
2\end{array}$ & 03 & & & $\begin{array}{l}\mathbf{0} \\
6\end{array}$ & & & & & & \\
\hline $\begin{array}{l}44 \text { Services for People with } \\
\text { Disabilities }\end{array}$ & & & & & & & & & & & & & & $\begin{array}{l}\mathbf{0} \\
2\end{array}$ & & & & & $\begin{array}{l}\mathbf{0} \\
7\end{array}$ & & & & & \\
\hline 45 Reading Advisory Services & & & & & & & & & & & & $\begin{array}{l}\mathbf{0} \\
\mathbf{0}\end{array}$ & & & & 04 & & & & & & 10 & $\begin{array}{l}1 \\
1\end{array}$ & \\
\hline 47 Storytelling & & & & & & & 95 & & & & & & & & & & & & & & & & $\begin{array}{l}1 \\
1\end{array}$ & \\
\hline 48 Reading and Literacy & & & & & 93 & 94 & & & & & $\begin{array}{l}9 \\
9\end{array}$ & $\begin{array}{l}\mathbf{0} \\
\mathbf{0}\end{array}$ & & $\begin{array}{l}\mathbf{0} \\
2\end{array}$ & & 04 & & $\begin{array}{l}0 \\
6\end{array}$ & $\begin{array}{l}\mathbf{0} \\
7\end{array}$ & & & 10 & $\begin{array}{l}1 \\
1\end{array}$ & \\
\hline $\begin{array}{l}49 \text { Information Literacy and } \\
\text { Instruction }\end{array}$ & & & & $\begin{array}{l}9 \\
2\end{array}$ & & & & & & & & & & $\begin{array}{l}\mathbf{0} \\
2\end{array}$ & & & $\begin{array}{l}\mathbf{0} \\
\mathbf{5}\end{array}$ & & $\begin{array}{l}\mathbf{0} \\
7\end{array}$ & & & & & \\
\hline $\begin{array}{l}50 \text { Information Needs and } \\
\text { Behaviors / Practices }\end{array}$ & & & & & $\begin{array}{l}9 \\
3\end{array}$ & $\begin{array}{l}9 \\
4\end{array}$ & $\begin{array}{l}9 \\
5\end{array}$ & & & & & & & & & & & & & & $\begin{array}{l}\mathbf{0} \\
9\end{array}$ & & & \\
\hline $\begin{array}{l}53 \text { Scholarly /Scientific } \\
\text { Communication }\end{array}$ & & & & & 93 & $\begin{array}{l}9 \\
4\end{array}$ & $\begin{array}{l}9 \\
5\end{array}$ & & & & & & & & & & & & & & $\begin{array}{l}\mathbf{0} \\
9\end{array}$ & & & \\
\hline 54 Organization of Information & & $\begin{array}{l}9 \\
\mathbf{0}\end{array}$ & & & & & & & & & & $\begin{array}{l}\mathbf{0} \\
\mathbf{0}\end{array}$ & & $\begin{array}{l}\mathbf{0} \\
\mathbf{2}\end{array}$ & $\begin{array}{l}\mathbf{0} \\
\mathbf{3}\end{array}$ & & & & & & & & & \\
\hline $\begin{array}{l}57 \text { Classification and Subject } \\
\text { Analysis }\end{array}$ & & & & & & $\begin{array}{l}9 \\
4\end{array}$ & & & & & & & & & & & & & & & & & & \\
\hline $\begin{array}{l}62 \text { Information Systems and } \\
\text { Technologies }\end{array}$ & & & $\begin{array}{l}9 \\
1\end{array}$ & & $\begin{array}{l}9 \\
3\end{array}$ & & & $\begin{array}{l}9 \\
6\end{array}$ & & & & $\begin{array}{l}\mathbf{0} \\
\mathbf{0}\end{array}$ & & & & & & & & $\begin{array}{l}\mathbf{0} \\
8\end{array}$ & & & & \\
\hline $\begin{array}{l}63 \text { Information Retrieval } \\
\text { Theory and Practice }\end{array}$ & & & & & & & & $\begin{array}{l}9 \\
6\end{array}$ & & & & & & & & & & & & & & & & \\
\hline $\begin{array}{l}64 \text { Online Catalog Retrieval } \\
\text { Systems }\end{array}$ & & & & & & & & & & $\begin{array}{l}9 \\
8\end{array}$ & & & & & $\begin{array}{l}\mathbf{0} \\
\mathbf{3}\end{array}$ & & & & & & & & & \\
\hline $\begin{array}{l}65 \text { Database and Other } \\
\text { Retrieval Systems }\end{array}$ & & & & & & & & & & $\begin{array}{l}9 \\
8\end{array}$ & $\begin{array}{l}9 \\
9\end{array}$ & & & & & & & & & $\begin{array}{l}\mathbf{0} \\
8\end{array}$ & & & & \\
\hline 67 Information Visualization & & & $\begin{array}{l}9 \\
1\end{array}$ & & $\begin{array}{l}9 \\
3\end{array}$ & & & & & & & & & & & & & & & & & & & \\
\hline $\begin{array}{l}68 \text { Computer/Information } \\
\text { Networks }\end{array}$ & & & & & & & & & 9 & & & $\begin{array}{l}\mathbf{0} \\
\mathbf{0}\end{array}$ & & & & $\begin{array}{l}0 \\
4\end{array}$ & & & & & & $\begin{array}{l}\mathbf{1} \\
\mathbf{0}\end{array}$ & & \\
\hline $\begin{array}{l}72 \text { Bibliometrics/Informetrics/ } \\
\text { Webometrics }\end{array}$ & & & & & $\begin{array}{l}9 \\
3\end{array}$ & & & & & & & $\begin{array}{l}\mathbf{0} \\
\mathbf{0}\end{array}$ & & & $\begin{array}{l}\mathbf{0} \\
\mathbf{3}\end{array}$ & & & & & & & & $\begin{array}{l}1 \\
1\end{array}$ & $\begin{array}{l}1 \\
2\end{array}$ \\
\hline 74 Digital/Virtual Libraries & & & & & & & & & & $\begin{array}{l}9 \\
8\end{array}$ & & & & & & & & & & & & & & \\
\hline $\begin{array}{l}77 \text { School Media Centers/ } \\
\text { Libraries }\end{array}$ & & & & $\begin{array}{l}9 \\
2\end{array}$ & & & & & & & & & & & & & & & & & & & & $\begin{array}{l}1 \\
2\end{array}$ \\
\hline 87 Building/Facilities & $\begin{array}{l}8 \\
9\end{array}$ & & & & & & & & & & & & & & & & & & & & & & & \\
\hline 89 Marketing & & & & & & & & & & $\begin{array}{l}9 \\
8\end{array}$ & & & $\begin{array}{l}\mathbf{0} \\
\mathbf{1}\end{array}$ & & & & & & $\begin{array}{l}\mathbf{0} \\
7\end{array}$ & & & & & \\
\hline 90 Evaluation of Service & & & & & & & & & & & & & & & & & & & & & & & & $\begin{array}{l}1 \\
2\end{array}$ \\
\hline 101 Curriculum Integration & & & & & & $\begin{array}{l}9 \\
4\end{array}$ & & & & & & & & & & & & & & & $\begin{array}{l}\mathbf{0} \\
9\end{array}$ & $\begin{array}{l}1 \\
\mathbf{0}\end{array}$ & & \\
\hline $\begin{array}{l}103 \text { Role of the School Media } \\
\text { Specialist }\end{array}$ & & $\begin{array}{l}9 \\
\mathbf{0}\end{array}$ & $\begin{array}{l}9 \\
1\end{array}$ & & & $\begin{array}{l}9 \\
4\end{array}$ & & & & & & & & & & & & & & $\begin{array}{l}\mathbf{0} \\
8\end{array}$ & & & & $\begin{array}{l}1 \\
2\end{array}$ \\
\hline 104 Instructional design & & & & & & & & & & & & & & & & & & & & & & & & $\begin{array}{l}1 \\
2\end{array}$ \\
\hline
\end{tabular}




\section{Conclusion}

In the Republic of Croatia, the school library community is the bigest community among other library types and librarians. The Croatian Bureau of Statistics (http://www.dzs.hr) reported that 1,178 school libraries operated in Republic of Croatia in 2010 . Out of that number there were 840 primary school libraries and 338 secondary school libraries. The school library staff consisted of 1,345 employees and served ca. 544,000 users (students, teachers, parents).

Croatian school librarians are generally educated librarians and information specialists for a wide range of vocations serving school libraries and libraries of other institutions including academic libraries. They have to be licensed by the Croatian Ministry of Education as a proof that they took appropriate courses in a subject area, passed a variety of tests, and/or met competency requirements. The certification or licensure then allows the person to teach or work in a school environment in a certain subject area for specific grade levels.

The yearly school librarian conferences started in 1989 and have continued up to now to promote professional knowledge in cooperation and interaction with worldwide library science scholars. Every conference started with a plenary session with the participation of educators and researchers with scholarly interests and expertise gained in a library environment. Library advisers to the goverment and governmental institutions are also represented here. Moreover, most of the time of these three-days conferences remain for the work presentation of school librarians in the form of lectures, workshops and best practice examples. They learn from each other how to interact with users, how to use their library skills in practice and how to cooperate on team project.

The discussions help them find suitable research projects in order to write their thesis in further education. It is also an opportunity for them to observe and discuss trends in the field of librarianship in general and in school librarianship in particular. Many active shools librarians made a good name for themselves by showing their work and become school library advisers and members of government bodies dealing with the problems and further devolopment of Croatian school librarianship.

We hope that our school library ontology model in the form of an overview of the reseach areas already involved in Croatian school librariran community will help all of us answer the challenge of building $21^{\text {st }}$ century learning and teaching environments.

The focus will be on seamless integration of knowledge, knowledge building rather than knowledge consumption, information, media, and universal access. It is becoming increasingly evident that the concept of flexibility (time and space) will shift the way education is delivered. With information readily available on the internet, synthesizing knowledge in order to innovate will be the challenge for the future schools. This speaks to the shift in the ways in which we teach students how to think, create, and problem solve. It will be incumbent upon schools to focus not on „what there is", but rather on ,what there could be".

The 24 years of preparation in more or less traditional and modern concepts of librarianship, i.e. LIS education, service to user populations, information systems and retrieval, development of LIS principles, curriculum, management, organization of information and information providers, as our ontology indicates, constitute a firm basis for coping with the challenges of learning and teaching in the 21 st century. 


\section{References}

Gruber T. R. (1993). A translation approach to portable ontology specifications. Knowledge Acquisition, 5,.199-220.

Gu, N., Jun, X., Xiaoyuan, W., Jiangming, Y., \& Wei, Y. (2005). Ontology based semantic conflicts resolution in collaborative editing of design documents. Advanced Engineering Informatics, 19, 103-111.

Hodge, G. (2012 April 26). Systems of knowledge organization for digital libraries. Beyond traditional authority files. Washington, DC: the Council on Library and Information Resources. Retrieved from http://www.clir.org/pubs/reports/pub91/contents.html

Poli, R. (2012 March 23). Descriptive, formal and formalized ongologies. Retrieved from

http://scholar.google.com/scholar_url?hl=en\&q=http://citeseerx.ist.psu.edu/viewdoc/do wnload\%3Fdoi\%3D10.1.1.177.6902\%26rep\%3Drep1\%26type\%3Dpdf\&sa=X\&scisig= AAGBfm2rhzURsbBOzVQs8Ue16z0-dqBEtg\&oi=scholarr

Reitz, J. M. (2012 May 25). ODLIS: Online dictionary for library and information science. Retrieved from http://www.abc-clio.com/ODLIS/odlis_L.aspx?\#libmediaspec \#

Svenonius, E. (2000). The intellectuall foundation of information organization. Cambridge, Mass. MIT Press. 